\title{
Tropospheric ozone climatology over Beijing: analysis of aircraft data from the MOZAIC program
}

\author{
A. J. Ding ${ }^{1}$, T. Wang ${ }^{1}$, V. Thouret ${ }^{2}$, J.-P. Cammas ${ }^{2}$, and P. Nédélec ${ }^{2}$ \\ ${ }^{1}$ Department of Civil and Structural Engineering, The Hong Kong Polytechnic University, Hong Kong, China \\ ${ }^{2}$ Laboratoire d'Aérologie, UMR 5560, Université Paul Sabatier, Toulouse, France
}

Received: 23 May 2007 - Published in Atmos. Chem. Phys. Discuss.: 5 July 2007

Revised: 14 November 2007 - Accepted: 29 November 2007 - Published: 4 January 2008

\begin{abstract}
Ozone $\left(\mathrm{O}_{3}\right)$ profiles recorded over Beijing from 1995 to 2005 by the Measurement of Ozone and Water Vapor by Airbus In-Service Aircraft (MOZAIC) program were analyzed to provide a first climatology of tropospheric $\mathrm{O}_{3}$ over Beijing and the North China Plains (NCPs), one of the most populated and polluted regions in China. A pooled method was adopted in the data analysis to reduce the influence of irregular sampling frequency. The tropospheric $\mathrm{O}_{3}$ over Beijing shows a seasonal and vertical distribution typical of midlatitude locations in the Northern Hemisphere, but has higher daytime concentrations in the lower troposphere, when compared to New York City, Tokyo, and Paris at similar latitude. The tropospheric $\mathrm{O}_{3}$ over Beijing exhibits a common summer maximum and a winter minimum, with a broad summer maximum in the middle troposphere and a narrower early summer (June) peak in the lower troposphere. Examination of meteorological and satellite data suggests that the lower tropospheric $\mathrm{O}_{3}$ maximum in June is a result of strong photochemical production, transport of regional pollution, and possibly also more intense burnings of biomass in CentralEastern China. Trajectory analysis indicates that in summer the regional pollution from the NCPs, maybe mixed with urban plumes from Beijing, played important roles on the high $\mathrm{O}_{3}$ concentrations in the boundary layer, but had limited impact on the $\mathrm{O}_{3}$ concentrations in the middle troposphere. A comparison of the data recorded before and after 2000 reveals that $\mathrm{O}_{3}$ in the lower troposphere over Beijing had a strong positive trend (approximately 2\% per year from 1995 to 2005) in contrast to a flat or a decreasing trend over Tokyo, New York City, and Paris, indicating worsening photochemical pollution in Beijing and the NCPs.
\end{abstract}

Correspondence to: T. Wang

(cetwang@polyu.edu.hk)

\section{Introduction}

Ozone $\left(\mathrm{O}_{3}\right)$ is a key trace gas in the troposphere owing to its important roles in atmospheric chemistry, air quality, and climate change. $\mathrm{O}_{3}$ determines the oxidizing capacity of the atmosphere through generation of the principal oxidizing agent, hydroxyl radical $(\mathrm{OH})$, and it is also an effective greenhouse gas in the upper troposphere (Crutzen, 1973; Fishman et al., 1979; Bojkov, 1988). High concentrations of $\mathrm{O}_{3}$ at ground level is of great concern because of its harmful effects on human health and vegetation (Mckee, 1994; NRC, 1991). Therefore, the temporal and spatial distribution of tropospheric $\mathrm{O}_{3}$ and the factors controlling its distribution has been a focus of atmospheric chemistry research.

While numerous studies were conducted in Europe, North America, and in Japan (Beekmann et al., 1994; Logan, 1985, 1994; Liu et al., 1987; Oltmans et al., 1998; Monks, 2000; Akimoto et al., 1994; Pochanart et al., 2002), there is limited knowledge of the temporal and spatial distribution of tropospheric $\mathrm{O}_{3}$ in China where rapid urbanization and industrial developments have been taken place in the latest two decades. Previous studies of emissions have projected sharp increases in the emissions of $\mathrm{O}_{3}$ precursors in China, especially in the fastest growing coastal regions of eastern China (Akimoto and Narita, 1994; Streets et al., 2003). Recently available satellite data have shown an increasing column concentrations of nitrogen dioxide, a precursor to $\mathrm{O}_{3}$, over China (Richter et al., 2005). Available ground-based measurements within China have shown frequent $\mathrm{O}_{3}$ pollution during photochemically active seasons in sub-urban and rural areas of these regions (e.g. Cheung and Wang, 2001; Wang and Kwok, 2003; Gao et al., 2005; Wang et al., 2006a). Seasonal cycles of surface ozone were reported at Lin'an in eastern China (Wang et al., 2001; Luo et al., 2000; Xu et al., 2007), a coastal background site (Hok Tsui) and a suburban site

Published by Copernicus Publications on behalf of the European Geosciences Union. 
(Tai O) in Hong Kong (Lam et al., 2001; Wang et al., 2005), a rural site (Shangdianzi) near Beijing (Liu et al., 2006), and three mountaintop sites (Mount Tai, Mount Hua, and Mount Huang) (Li et al., 2007).

Monthly mean $\mathrm{O}_{3}$ concentration was found to reach a maximum in early summer (May or June) in central and eastern China and in autumn in southern China. Vertical distribution of $\mathrm{O}_{3}$ in the troposphere over China has been examined using ozonesondes which were launched mainly during intensive campaigns (Chan et al., 2003; Zheng et al., 2004). Using satellite data from GOME (Global Ozone Monitoring Experiment), Fishman et al. (2003) showed higher tropospheric $\mathrm{O}_{3}$ residual in eastern China than in other midlatitude regions of the Northern Hemisphere. Nevertheless, additional data on $\mathrm{O}_{3}$ are needed in many parts of China, particularly the data that give vertical distribution and long-term trend of tropospheric $\mathrm{O}_{3}$.

In this study we analyze $\mathrm{O}_{3}$ profiles obtained during 19952005 by the Measurement of Ozone and Water Vapor by Airbus In-Service Aircraft (MOZAIC) Program (http://mozaic. aero.obs-mip.fr/web/) to investigate the climatology of tropospheric $\mathrm{O}_{3}$ distribution over Beijing. Since 1994, $\mathrm{O}_{3}$ and other trace gases have been routinely measured on board commercial airliners flying between large cities around the world, including three mega-cities in China: Beijing, Shanghai, and Hong Kong. This program has generated a unique dataset for studying tropospheric $\mathrm{O}_{3}$. In this work, we focus on the $\mathrm{O}_{3}$ distribution over Beijing and the surrounding areas for the following reasons. First, this region is one of the most polluted parts of China. For instance, 200-300 ppbv of $\mathrm{O}_{3}$ has been reported in urban and rural areas of Beijing (Shao et al., 2006; Wang et al., 2006a). Second, Beijing will host the 2008 Summer Olympics; poor air quality (including summertime photochemical $\mathrm{O}_{3}$ pollution) is of a paramount concern of the central and municipal governments. Third, in China MOZAIC data have been collected over the longest period in Beijing. We examine the temporal and vertical distributions of $\mathrm{O}_{3}$ and the trend during 1995-2005, and with aid of meteorological and satellite data we discuss the role of emission, dynamic transport, and photochemistry.

\section{Data and methodologies}

\section{1 $\mathrm{MOZAIC} \mathrm{O}_{3}$ data over Beijing}

The Measurement of Ozone and Water Vapor by Airbus InService Aircraft (MOZAIC) program has been designed to routinely observe $\mathrm{O}_{3}$ and water vapor along flight routes using automatic instruments installed onboard commercial airliners(Marenco et al., 1998). The five (now three) MOZAIC aircraft make near-daily flights between Europe and a variety of destinations throughout the world. $\mathrm{O}_{3}$ was measured using the dual-beam UV absorption analyzer (Thermo Environment Instruments - Model 49-103), with an overall measure- ment precision of \pm 2 ppbv. The sensors were recalibrated after every 500 flight hours (Thouret et al., 1998a, 2006). More details of this program can be found on the MOZAIC website (http://mozaic.aero.obs-mip.fr/web/).

In the present study, we mainly draw on $\mathrm{O}_{3}$ profiles recorded in the ascent and descent stages of the flights during 1994-2005 over Beijing and three other mega-cities in the northern mid-latitudes: New York City, Tokyo, and Paris. The raw MOZAIC data have a temporal resolution of $4 \mathrm{~s}$, i.e. about $30 \mathrm{~m}$ vertically. We use the reprocessed data with a vertical resolution of $250 \mathrm{~m}$ below $2 \mathrm{~km}$ and $500 \mathrm{~m}$ above $2 \mathrm{~km}$. For Beijing, there were about 800 profiles taken by this program from March 1995 to August 2005. In other mega-cites, more profiles (about 1300, 4400, and 3300 for Tokyo, Paris, and New York, respectively) were obtained during 1994-2005.

Figure 1a gives the geographical coverage of the MOZAIC flight routes around Beijing on a topographical and land-use map, and Fig. 1b and $\mathrm{c}$ show the distribution of the number of profiles as a function of month and the local time of day, respectively. From Fig. 1a, it can be clearly seen that Beijing is located on the north side of the North China Plains (NCPs), and the Beijing Capital International Airport sits northeast to the urban center with a distance of about $25 \mathrm{~km}$. Both urban Beijing and the airport are embraced by mountains in the west, north and northeast, with heights ranging from several hundreds meters to $3 \mathrm{~km}$. Figure 1a also shows that the MOZAIC aircraft descended and ascended along relatively fixed routes, circling near the airport on the east side. We used the data collected within a box of 3 by $3^{\circ}$ in longitude/latitude $\left(115.5-118.5^{\circ} \mathrm{E}, 39.0-42.0^{\circ} \mathrm{N}\right)$ with Beijing in the center of the box (see the blue dashed box in Fig. 1a). Figure $1 \mathrm{~b}$ shows that there was large year-to-year difference in the number of profiles recorded, with more data collected during 1997-1998 and around 2005. Figure 1c shows that most of the profiles over Beijing were taken in the daytime (05:00-17:00, local time LT). Other cities may have different diurnal distributions of sample numbers; in New York City, for example, most of profiles were taken within 10:0023:00 LT (Thouret et al., 1998b).

2.2 Meteorological and satellite data, and trajectory calculation

To help interpret the MOZAIC $\mathrm{O}_{3}$ profiles, we use various meteorological and satellite data, and back trajectories. A brief description of these data and products is given below.

The meteorological data include twice-a-day (00:00 and 12:00 Greenwich time) radiosonde data, surface wind and rainfall data measured at Beijing Observatory (from CISL at NCAR, http://dss.ucar.edu/datasets/), monthly mean sunshine hours and rainfall data at Beijing (Chinese Statistical Yearbook 1996-2006, http://www.stats.gov.cn/tjsj/ ndsj/), and monthly mean NCEP/NCAR reanalysis data, with a resolution of $2.5^{\circ}$ in latitude and longitude 

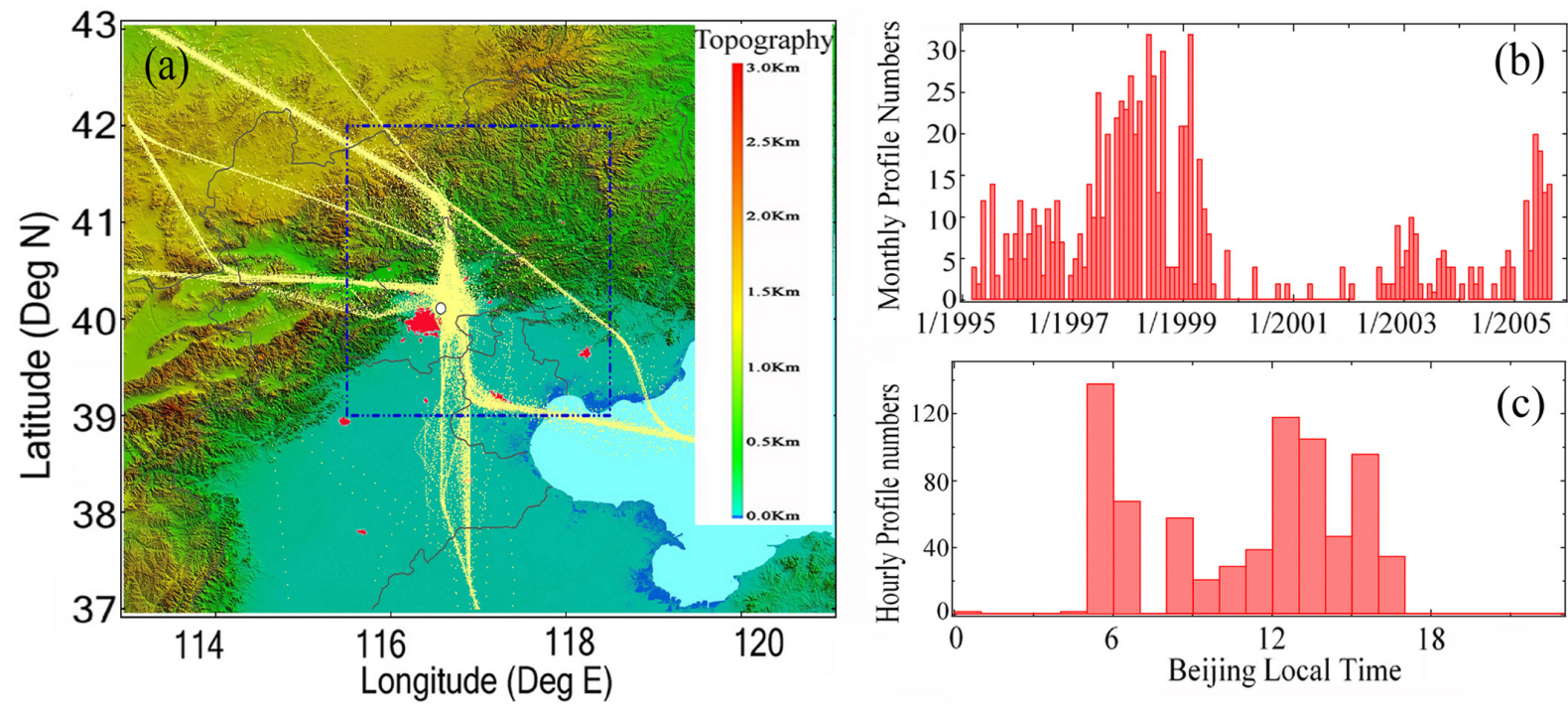

Fig. 1. (a) Geographical coverage of the MOZAIC flight routes around Beijing during 1995-2005, presented on topographical map with urban area colored red, and distributions of the total number of vertical profiles as a function of (b) month, and (c) of the time of day. The legend in Fig. 1a shows the scale of terrain.

(from NOAA CDC, http://www.cdc.noaa.gov/cdc/data.ncep. reanalysis2.html.

Two kinds of satellite data were used to provide the regional perspective of air pollutants. One is the monthly mean global tropospheric $\mathrm{NO}_{2}$ column, with a $0.5^{\circ}$ resolution, obtained by GOME (Global Ozone Monitoring Experiment, 1995-2002) and SCIAMACHY (SCanning Imaging Absorption spectroMeter for Atmospheric CHartographY, 2003-present) (data were obtained via TEMIS, http:// www.temis.nl/index.html). Another one is the nighttime fire count product retrieved from ATSR-2 (Along Track Scanning Radiometer 2) using Algorithm\#2 (http://dup.esrin.esa. int/ionia/about_ionia.asp).

To help understand the influence of long-range transport on the vertical distribution of tropospheric $\mathrm{O}_{3}$, we calculated back-trajectories using HYSPLIT (HYbrid SingleParticle Lagrangian Integrated Trajectory, version 4.8) model of NOAA Air Resources Laboratory (http://www.arl.noaa. gov/ready/hysplit4.html). The formated Final Analysis data (FNL) with a horizontal resolution of about $190 \mathrm{~km}, 13$ vertical layer and 6-h temporal resolution were used to drive the model.

\subsection{Pooled statistical analysis}

Vertical profiles from the aircraft survey provide "snapshots" of $\mathrm{O}_{3}$ distribution for a relatively short period of time. As shown in Fig. 1b and c, the sampling frequency of MOZAIC $\mathrm{O}_{3}$ profile is not evenly distributed seasonally and diurnally. Therefore the conventional averaging method may not truly represent the overall mean behavior of $\mathrm{O}_{3}$, particularly in the lower troposphere where $\mathrm{O}_{3}$ has strong seasonal and diurnal variations. In the present work we adopt a pooled statistical method introduced by Taylor and Cihon (2004).

The concept of pooled statistical analysis is to divide the data into several groups (of same season and/or of same time of day), and then pool their means and standard deviations (SDs) together. If the $\mathrm{O}_{3}$ data at a certain height were defined as $\hat{X}$, we first divide them into $\mathrm{N}$ groups $\hat{X}_{i}(\mathrm{i}=1,2 \ldots \mathrm{N})$, and then calculate the mean $\left(\bar{X}_{i}\right)$ and $\mathrm{SD}\left(S_{i}\right)$ of each group. We then have the pooled average as:

$\bar{X}_{p}=\frac{1}{\mathrm{~N}} \sum\left(\bar{X}_{i}\right)$.

and pooled SD as:

$S_{p}=\sqrt{\frac{\sum S_{i}^{2} \cdot\left(M_{i}-1\right)}{\sum\left(M_{i}-1\right)}}$.

where $M_{i}$ is the number of data points of the $i$ th group. The value for $S_{p}$ is based on degrees of freedom as

$d f_{p}=\sum\left(M_{i}-1\right)$.

\section{Results and discussions}

3.1 Overall results over Beijing and a comparison with other cities

Figure 2 gives the vertical distributions of $\mathrm{O}_{3}$ below $10 \mathrm{~km}$ using two different statistical methods: the conventional method (i.e. grand average) and the pooled method with data 


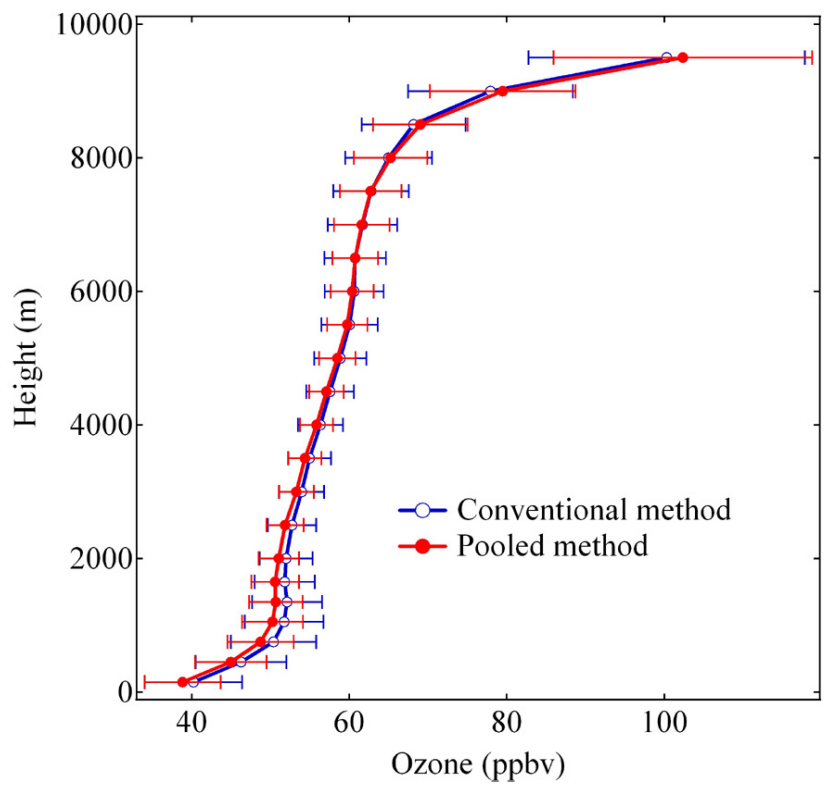

Fig. 2. Distributions of tropospheric $\mathrm{O}_{3}$ (Mean $\pm 0.5 \mathrm{sd}$ or $\pm 0.5 S_{p}$, same in other figures) over Beijing using conventional and pooled statistical methods.

being divided into 24 groups ( 12 months $\times 2$ periods of day 05:00-10:00 LT and 11:00-16:00 LT). It can be seen that the two methods give a very similar vertical distribution of $\mathrm{O}_{3}$, with a difference of $1-2 \mathrm{ppbv}$ in the mean values. However the SDs of the pooled method were obviously smaller, especially in the Planetary Boundary Layer (PBL). Given a decrease of 24 in degrees of freedom (from a total of 810 profiles), the pooled method should provide results with a larger statistical significance.

Figure 2 shows that the mixing ratio of $\mathrm{O}_{3}$ increased from $\sim 40 \mathrm{ppbv}$ at ground to $\sim 65 \mathrm{ppbv}$ around $8 \mathrm{~km}$, and then increased rapidly above $8 \mathrm{~km}$ with a larger variability near the tropopause. Such a mean $\mathrm{O}_{3}$ distribution is typical for locations in mid-latitudes (Logan, 1994; Beekmann et al., 1994; Thouret et al., 1998b; Cooper et al., 2005). In the PBL the $\mathrm{O}_{3}$ concentrations increased sharply below $1 \mathrm{~km}$ and then remained fairly constant $(\sim 52 \mathrm{ppbv})$ between $1 \mathrm{~km}$ and $2 \mathrm{~km}$. This feature is mainly related to the diurnal cycle of $\mathrm{PBL} \mathrm{O}_{3}$, which will be further discussed in Sect. 3.2.

Figure 3a-c compare the lower tropospheric $\mathrm{O}_{3}$ over Beijing with the profiles obtained over Tokyo, Paris, and New York City using non-pooled method with data collected at all time (Fig. 3a) and the common daytime (10:00-14:00) in the four cities (Fig. 3b), and pooled method with daytime data (4 seasons $\times 5$ h (10:00-14:00)) (Fig. 3c), respectively. All the three figures show the highest mean $\mathrm{O}_{3}$ concentrations in the lower troposphere over Beijing. The pooled method, with the best statistical significance, shows about $10 \mathrm{ppbv}$ higher in the PBL ozone in Beijing. This indicates that Beijing has higher tropospheric $\mathrm{O}_{3}$ concentrations than those at megacities of the similar latitudes in Europe, Japan, and the eastern United States. This result is consistent with the work of Fishman et al. (2003) who showed higher tropospheric $\mathrm{O}_{3}$ residual in eastern China based on an analysis of GOME data.

\subsection{Diurnal variation of lower tropospheric $\mathrm{O}_{3}$}

Figure 4a to $\mathrm{c}$ show mean diurnal patterns of $\mathrm{O}_{3}$ from ground to $3.5 \mathrm{~km}$ altitude over Beijing for whole year, summer, and winter. The annual mean results (Fig. 4a) are pooled from data collected in the four seasons (Month F-M-A as spring, M-J-J as summer, A-S-O as autumn, and N-D-J as winter). We define M-J-J as summer to consider the early summer maxima of lower tropospheric $\mathrm{O}_{3}$ (see Sect. 3.3).

The PBL $\mathrm{O}_{3}$ over Beijing showed a strong diurnal cycle in summer and a much weaker one in winter. In the early morning (05:00-08:00 LT) of summer, $\mathrm{O}_{3}$ was very low at the surface ( $\sim 25 \mathrm{ppbv})$ and had a strong concentration gradient below $1 \mathrm{~km}$. This is a typical $\mathrm{O}_{3}$ distribution in nocturnal and morning PBL (Kleinman et al., 1994; Hidy, 2000; Cheung and Wang, 2001), which is a combined result of dry deposition, surface uptake, and chemical destruction (e.g. titration of NO) in the stable nocturnal PBL (Logan, 1985; Reiter, 1991; Neu et al., 1994).

After 08:00 LT, the PBL $\mathrm{O}_{3}$ gradually increased with an annual mean rate of $3 \sim 4 \mathrm{ppbv} \mathrm{h}^{-1}$ and a much higher summertime rate $\left(6-7 \mathrm{ppbv} \mathrm{h}^{-1}\right)$ in the lower PBL where the precursors were often of very high concentrations. The rapid $\mathrm{O}_{3}$ increase in the morning has been mainly attributed to downward transport of $\mathrm{O}_{3}$-rich air mass after the breakup of the nocturnal PBL (Reiter, 1991; Mckendry and Lundgren, 2000; Cheung and Wang, 2001). In the afternoon, the PBL $\mathrm{O}_{3}$ concentrations reached the daily maximum at 13:00-14:00 LT in summer but at 15:00-16:00 LT on annual average. The afternoon maximum of $\mathrm{PBL} \mathrm{O}_{3}$ is a typical feature downwind of an urban area, and the peak time often depends on the distance from the city (Logan, 1989; Wang et al., 2001, 2005, 2006a). The diurnal variation of MOZAIC $\mathrm{O}_{3}$ in the lower PBL is similar to those measured in summer 2005 at a mountainous site about $50 \mathrm{~km}$ north of the center of Beijing (Wang et al., 2006a).

Since the MOZAIC aircraft routes cover a large area around Beijing (see Fig. 1) the data can thus provide useful information on the spatial-temporal variations of PBL $\mathrm{O}_{3}$. Figures $5 \mathrm{a}$ to $\mathrm{i}$ show the gridded mean summertime $\mathrm{O}_{3}$ concentrations at different altitudes in the lower troposphere (horizontal resolution: $\sim 4 \mathrm{~km}$; vertical interval: $0.8 \mathrm{~km})$ in early morning (05:00-08:00 LT), later morning (09:00-12:00 LT) and afternoon (13:00-16:00 LT). These figures reveal that high $\mathrm{O}_{3}$ concentrations generally appeared in northeastern and eastern suburban areas of Beijing in summer. In comparison, frequent $\mathrm{O}_{3}$ pollution episodes have been observed at the ground level in mountainous areas north 

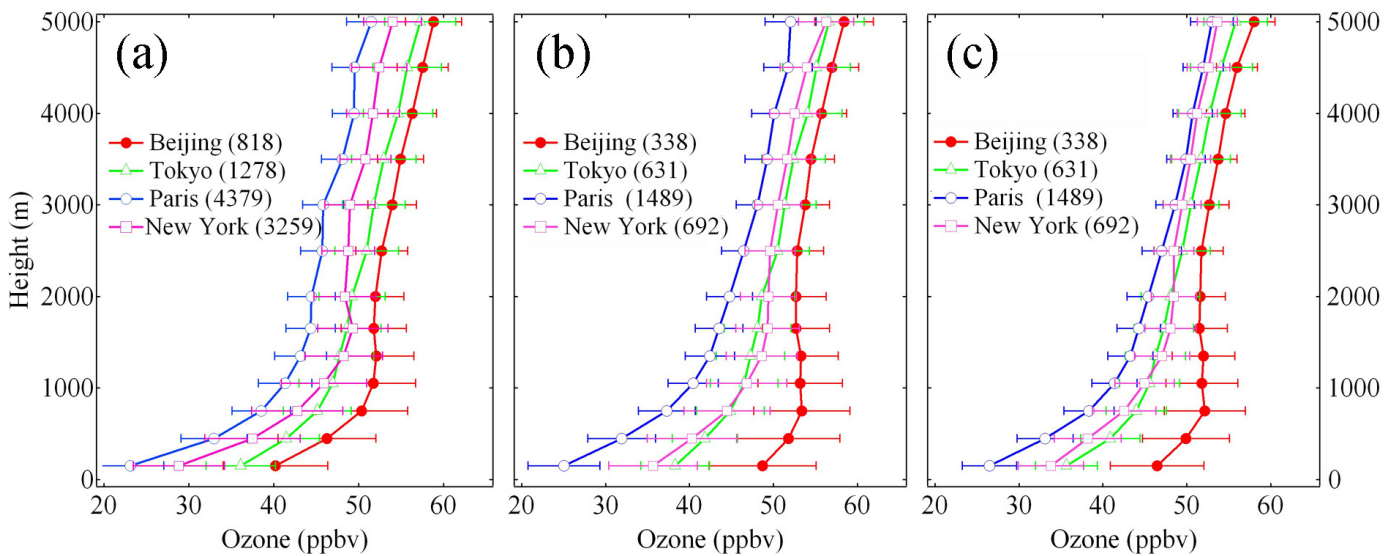

Fig. 3. Comparison of $\mathrm{O}_{3}$ distributions in low troposphere over Beijing $\left(39.9^{\circ} \mathrm{N}\right)$, Tokyo $\left(35.7^{\circ} \mathrm{N}\right)$, Paris $\left(48.8^{\circ} \mathrm{N}\right)$, and New York City $\left(40.7^{\circ} \mathrm{N}\right)$, using conventional average with (a) all data and (b) the data recorded between 10:00-14:00 LT, and (c) using pooled method with the daytime data $(4$ seasons $\times 5 \mathrm{~h}(10: 00-14: 00 \mathrm{LT})$, respectively. The total number of valid profiles used in statistics for each city is given in the parentheses.
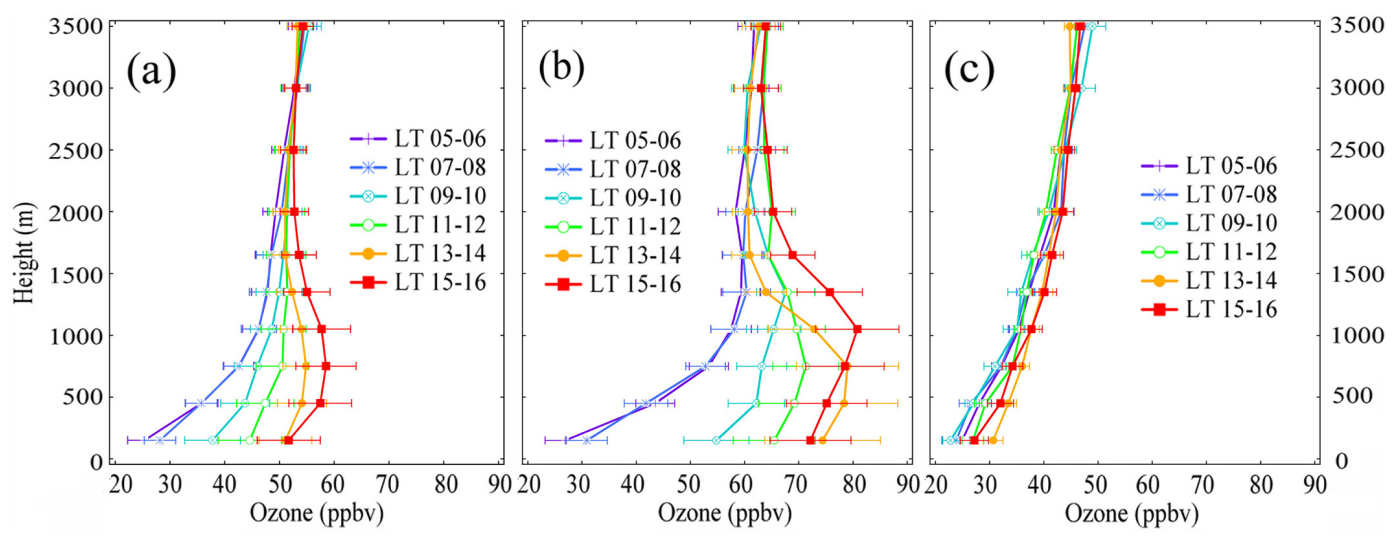

Fig. 4. Diurnal patterns of $\mathrm{O}_{3}$ profiles for (a) annual average, (b) summer (MJJ), and (c) winter (NDJ) in the lower troposphere.

of Beijing during summer (Wang et al., 2006a), which has been attributed to mountain-valley breezes transporting urban plumes to the north.

\subsection{Seasonal cycles of tropospheric ozone and their causes}

\subsubsection{Seasonal changes in tropospheric ozone and their re-} lations to meteorological conditions

$\mathrm{O}_{3}$ throughout the troposphere exhibits a seasonal cycle, and the exact pattern and the underlying causes can vary at different locations (Monks, 2000). In Fig. 6a, we show the seasonal patterns of $\mathrm{O}_{3}$, pooled from two daytime periods (05:00-10:00 LT and 11:00-16:00 LT), over Beijing at four altitude bins. It can be seen that the $\mathrm{O}_{3}$ concentrations had a summer maximum and a winter minimum throughout the troposphere: a broad summer maximum (May-August) was observed in the middle troposphere $(4 \mathrm{~km}-8 \mathrm{~km})$; while a sharper early summer peak (in June) was found in the lower troposphere (below $4 \mathrm{~km}$ ).

A broad summer maximum of $\mathrm{O}_{3}$ in the middle troposphere has been widely observed in Europe and North America and was mainly attributed to photochemical production (Liu et al., 1987; Logan, 1999; Law et al., 2000; Zbinden et al., 2006). Analysis of data in Japan showed that middle-tropospheric $\mathrm{O}_{3}$ exhibit a summer maximum in northern Japan and a spring maximum and a summer minimum in the southern parts (Logan, 1989; Austin and Midgley, 1994; Thouret et al., 1998b; Naja and Akimoto, 2004). This phenomenon has been attributed to the influence of the Asian summer monsoons which bring maritime air with low $\mathrm{O}_{3}$ air from the tropical Pacific to southern Japan (Logan, 1989; Thouret et al., 1998b). In the interior region of the Asian continent, a summer maximum of $\mathrm{O}_{3}$ was observed over the northeastern Tibet-Qinghai Plateau 


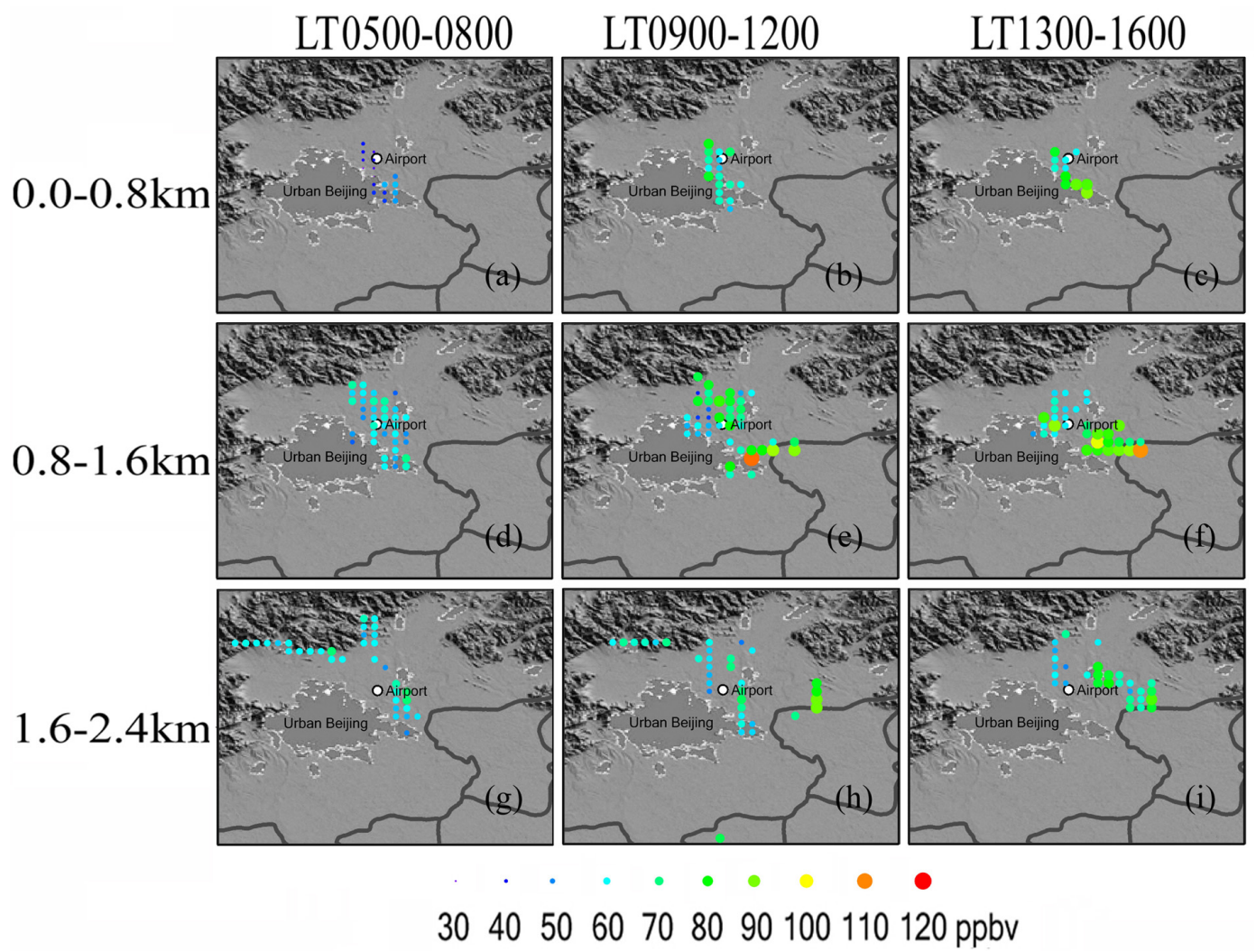

Fig. 5. Horizontal distributions of mean $\mathrm{O}_{3}$ concentrations around Beijing at different altitudes of the lower troposphere for different daytime periods in summer $(\mathrm{MJJ})$.

(Wang et al., 2006b), which has been attributed to a possible source of stratosphere-to-troposphere exchange (Ding and Wang, 2006). For the broad mid-tropospheric summer maximum of $\mathrm{O}_{3}$ over Beijing, another important source may be the biomass burnings in Central Asia and Russia (Pochanart et al., 2003; Nedelec et al., 2005; Qin et al., 2006), whose plumes can be rapidly transported to middle and even upper troposphere by warm conveyor belts (Nedelec et al., 2005; Real et al., 2007).

The June peak of $\mathrm{O}_{3}$ in the lower troposphere in Beijing is most likely the result of photochemical production from anthropogenic sources. Wang et al. (2001) showed an early summer maxima of surface $\mathrm{O}_{3}$ (in May) at Lin'an, in centraleastern China just before the rainy season starts in that region, while southern China had an annual maximum in autumn (Lam et al., 2001; Wang et al., 2005). The different seasonal patterns can be explained by distinct meteorological conditions in different parts of China. To learn about the relationship between meteorological conditions and the seasonal patterns of $\mathrm{O}_{3}$ over Beijing, we examined seasonal variations in monthly mean wind, sunshine hours, and total rainfall measured at the Beijing Observatory during 1995-2005 (Fig. 6b). It shows that the lower tropospheric wind blew more southerly in summer due to the onset of the Asian sum- mer monsoons. The mean daily sunshine hours decreased significantly from June to July and August accompanying a sharp increase in total rainfall, indicating that the monsoons in late summer bring more frequent rainy/cloudy weather conditions to Beijing. The reduced sunlight and increased rainfall in July and August can partially explain the reduced $\mathrm{O}_{3}$ concentrations in the two month compared to June.

To examine if there was an unusual source of emission contributing to the June $\mathrm{O}_{3}$ maxima, such as open-field burning of crop residues, we show the monthly mean tropospheric $\mathrm{NO}_{2}$ column retrieved from GOME and SCIAMACHY satellite for June (Fig. 7a) and August (Fig. 7b), and in Fig. 7c and $\mathrm{d}$ we also present the ATSR-2 total fire count maps for the two months. Here we combined the GOME and SCIAMACHY data to calculate the average of the $\mathrm{NO}_{2}$ column. The same treatment has been adopted by others (e.g. Richter et al., 2005). Inspection of these figures clearly reveals a difference in tropospheric $\mathrm{NO}_{2}$ column and biomass burning activities between June and August. The very intensive biomass burnings in June were mostly related to the harvest of wheat in the NCPs and East China (Wang et al., 2002). Besides the decreased contribution from the biomass burning emissions, the reducing tropospheric $\mathrm{NO}_{2}$ column in August could also be due to a faster removal of $\mathrm{NO}_{2}$ via hydrolysis and direct 
rainout under more dumid conditions in that month. To further estimate the relative contribution from biomass burning, we compared the tropospheric total $\mathrm{NO}_{2}$ column over Beijing in June (with active fires) and the averaged $\mathrm{NO}_{2}$ column in May and July (with fewer fires), assuming a same anthropogenic emission of $\mathrm{NO}_{2}$ in these months. The result suggests that biomass burning contributes about $20 \%$ of the $\mathrm{NO}_{2}$ column in June over Beijing, indicating an important impact to ozone from the agricultural burnings activities.

Besides photochemical production and removal, longrange transport can also play a role in the seasonal cycle of $\mathrm{O}_{3}$. To see if the there is a change in the Asian summer monsoons from June to August, in Fig. 8a-d we show the mean geopotential heights and streamlines at $1000 \mathrm{hPa}$ and $850 \mathrm{hPa}$ levels in June and August for 1995-2005. A comparison of Fig. 8a and c suggests that the southern, eastern and northern China are dominated by the summer monsoons in both months: in June the surface winds over Beijing were mostly from the south in contrast to a southeasterly wind in August (see marked arrows). At the $850 \mathrm{hPa}$ level, winds came mainly from southwest in June and southeast in August (see Fig. $8 \mathrm{~b}$ and d). The change in the circulations of the Asian monsoon system between the two months can be attributed to the northward movement of subtropical high over the Pacific (Ding, 1994), which can also be seen from the geopotential heights given in Fig. $8 \mathrm{~b}$ and d. These results suggest that Beijing was more influenced by regional pollution sources in the polluted NCPs in June. The more frequent impact of maritime air masses in August is the main cause of the cloudy/rainy weather in Beijing. In summary, favorable meteorological conditions such as stronger solar radiation and a prevailing southerly wind (facilitating transport of regional emissions) and more intensive biomass burning activities in June could be the cause of the narrow seasonal $\mathrm{O}_{3}$ peak observed in June over Beijing.

\subsubsection{The impact of long-range transport on tropospheric $\mathrm{O}_{3}$ in summer}

In this section we use back-trajectory analysis to gain further insights into contributions from different source regions to the $\mathrm{O}_{3}$ concentrations at different altitudes of the troposphere over Beijing. Three-day 3-D back-trajectories were calculated at 07:00-08:00 LT, 11:00-12:00 LT, and 15:0016:00 LT for all profiles collected in summer months (M-J-J) during 1995-2005. The endpoints of the trajectories were at $1.2 \mathrm{~km}, 3 \mathrm{~km}$ and $5 \mathrm{~km}$ over the airport, representing the upper PBL, the lower free troposphere and the middle troposphere, respectively. All trajectories were ended at the airport, not at exact locations on aircraft routes. In Fig. 9ac, we show the classified trajectories at the three altitudes based on their origins and pathways. The PBL trajectories was classified into two categories (Fig. 9a): one group (N) was transported from the remote areas in the north with fast wind speeds; the other (S) was originated from the polluted

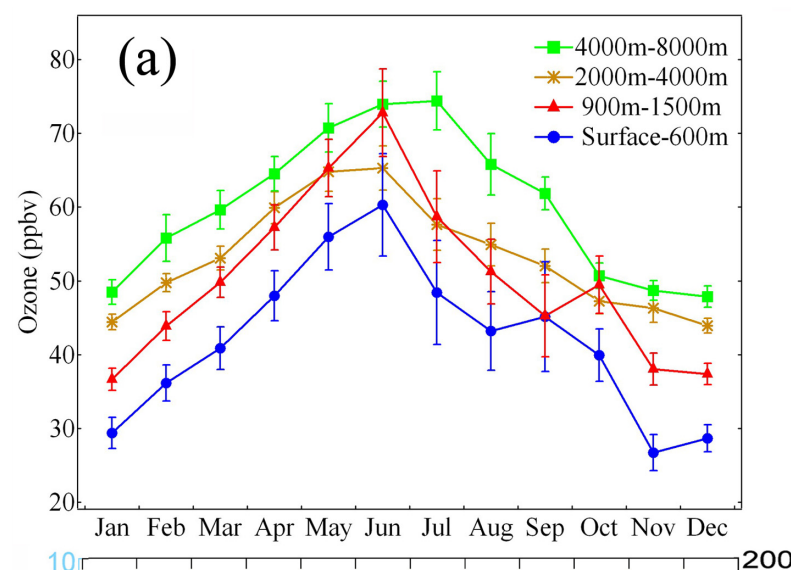

(b)

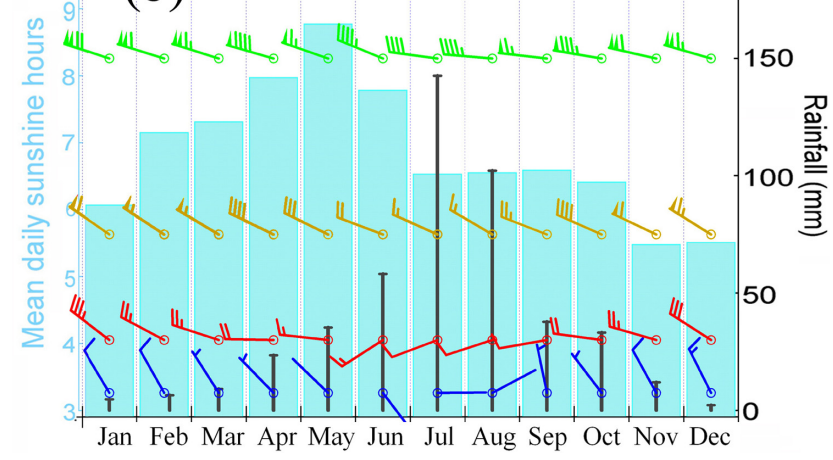

Fig. 6. Seasonal variations of (a) $\mathrm{O}_{3}$ concentrations at different tropospheric levels over Beijing, and of (b) wind profiles, mean sunshine hours and monthly total rainfall at Beijing.

regions in the south with low wind speeds. For the higher altitudes (Fig. $9 \mathrm{~b}$ and c), besides the $\mathrm{N}$ and $\mathrm{S}$ air-mass types in the PBL, a third air-mass type from west (W) was identified. The vertical tracks of these trajectories, showing as latitudeheight plots, are given on the right side of these figures.

Based on the trajectory classifications at the three altitudes, we calculated the mean $\mathrm{O}_{3}$ profiles for each air-mass group at different vertical layers from surface to $6 \mathrm{~km}$, which are shown in Fig. 10, together with the total number of $\mathrm{O}_{3}$ profiles in each category. It can be seen that below $2 \mathrm{~km}$ the profile number of Type $\mathrm{N}$ is smaller than that of Type $\mathrm{S}$, but above $2 \mathrm{~km}$ the opposite is true, which indicates that the summer monsoons mainly influence the lower troposphere. Below $2 \mathrm{~km}$, air masses from the south contained higher $\mathrm{O}_{3}$ concentrations (by 10-15 ppbv) than that from the north with the largest difference occurring at $1 \mathrm{~km}$ altitude. This is what one expects to see as the air from the north was less influenced by emissions in the NCPs. Interestingly air masses arriving from the west also contained elevated $\mathrm{O}_{3}$ concentrations in the lower free troposphere $(2-4 \mathrm{~km})$. A comparison of $\mathrm{O}_{3}$ profiles for Categories $\mathrm{W}$ and $\mathrm{N}$ suggests a larger difference in lower altitudes, which suggests that the elevated 

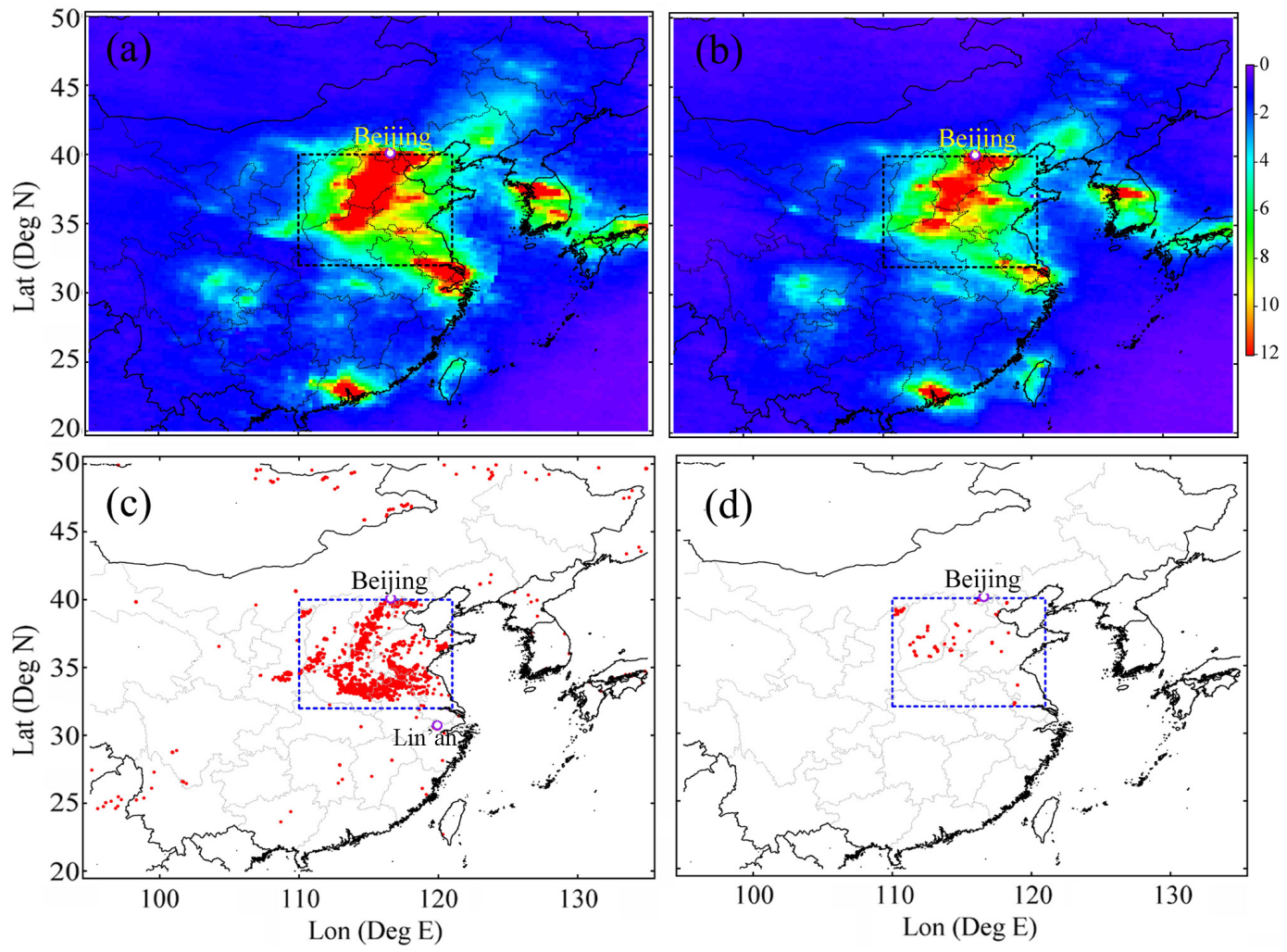

Fig. 7. Climatology of tropospheric $\mathrm{NO}_{2}$ column retrieved from GOME (1995-2002) and SCIAMACHY (2003-2005) satellite data in (a) June and (b) August during 1995-2005, and ATSR-2 total fire count map in (c) June and (d) August during 1996-2005.
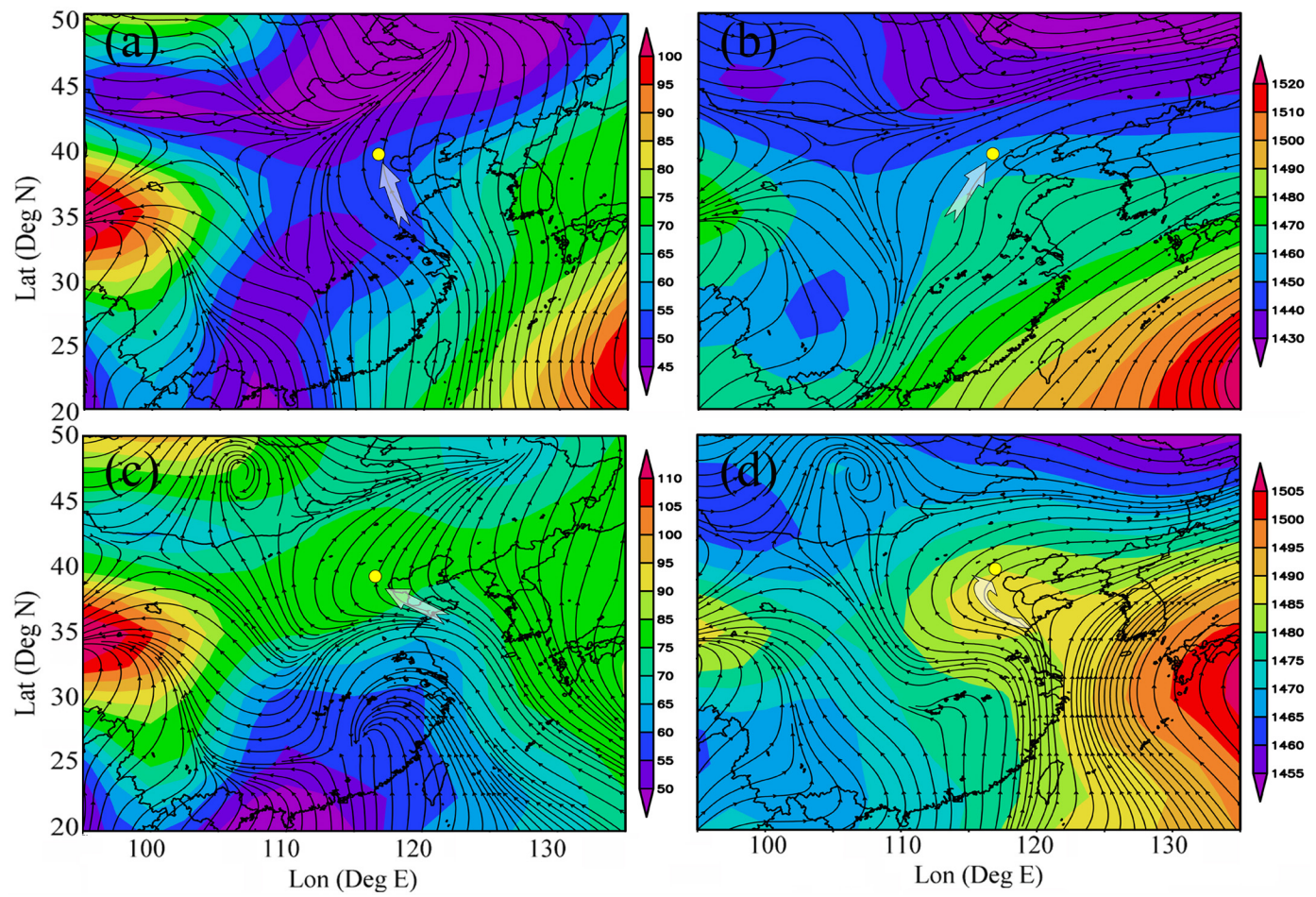

Fig. 8. Monthly mean geopotential heights (see color scale) and streamlines, (a) at $1000 \mathrm{hPa}$ in June, (b) at $850 \mathrm{hPa}$ in June, (c) at $1000 \mathrm{hPa}$ in August, and (d) at $850 \mathrm{hPa}$ in August, during 1995-2005. 

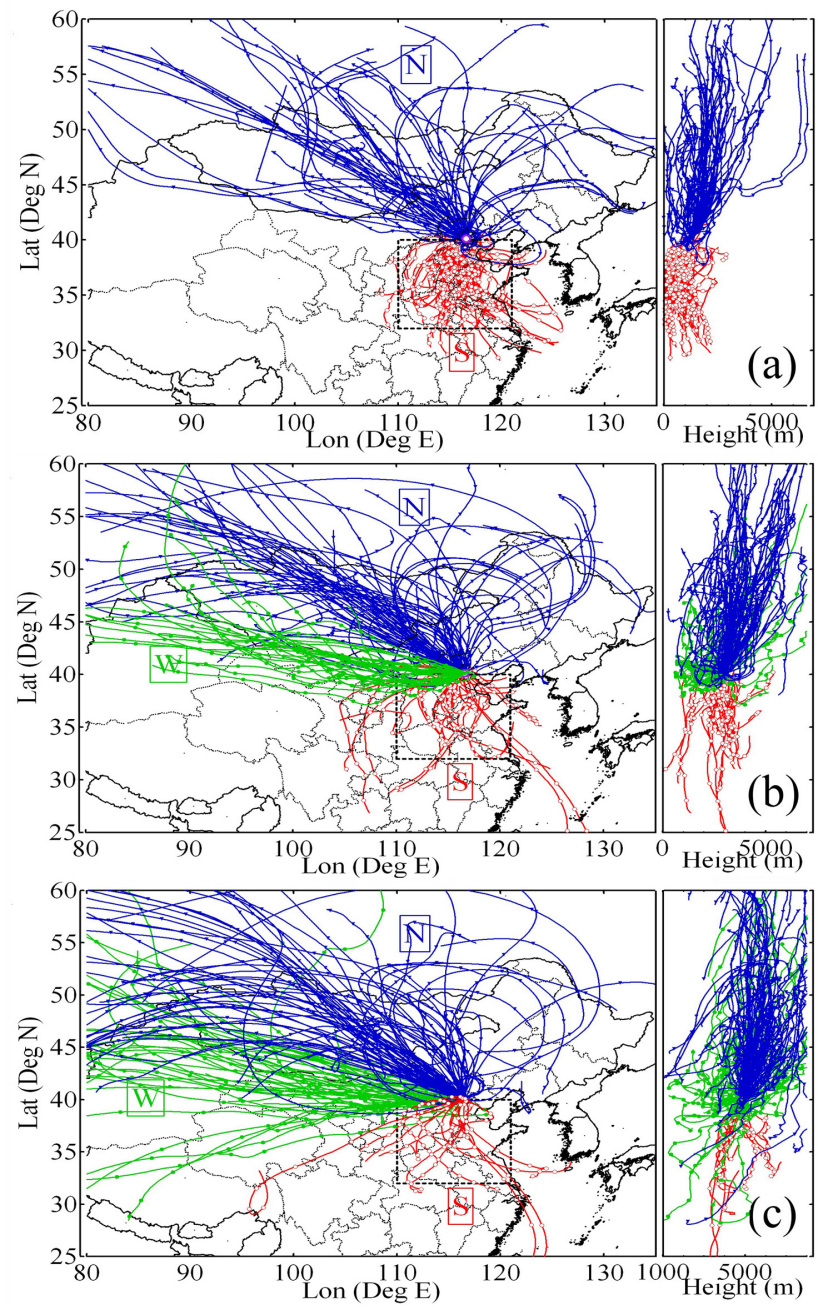

Fig. 9. Clusters of 3-day back-trajectories ending at (a) $1.2 \mathrm{~km}$, (b) $3 \mathrm{~km}$, and (c) $5 \mathrm{~km}$ over Beijing during May-July. The right side parts of these figures show the vertical locations of trajectories as a function of latitude.

ozone should be related to surface sources rather than the large-scale background. However, the 3-day back trajecotries do not indicate obvious source for the elevated ozone associated with the westerly transport at 2-4 km. Further modelling study are required to ascertain the origins which could be due to long range transport from distant source regions such as Europe, or perhaps to a more local orgin in the NCPs which is not resolved well by these back trajectories with a relatively coarse spatial and temporal resolution.

In the free troposphere, the mean $\mathrm{O}_{3}$ concentrations of Type $\mathrm{S}$ decreased significantly and were even lower than those from the north and the west above $4 \mathrm{~km}$. This further reveals that the broad mid-tropospheric summer maximum over Beijing was not caused by anthropogenic emissions convected from the NCPs and the Central-Eastern China, but probably reflect the overall mid-latitude cycle of mid-

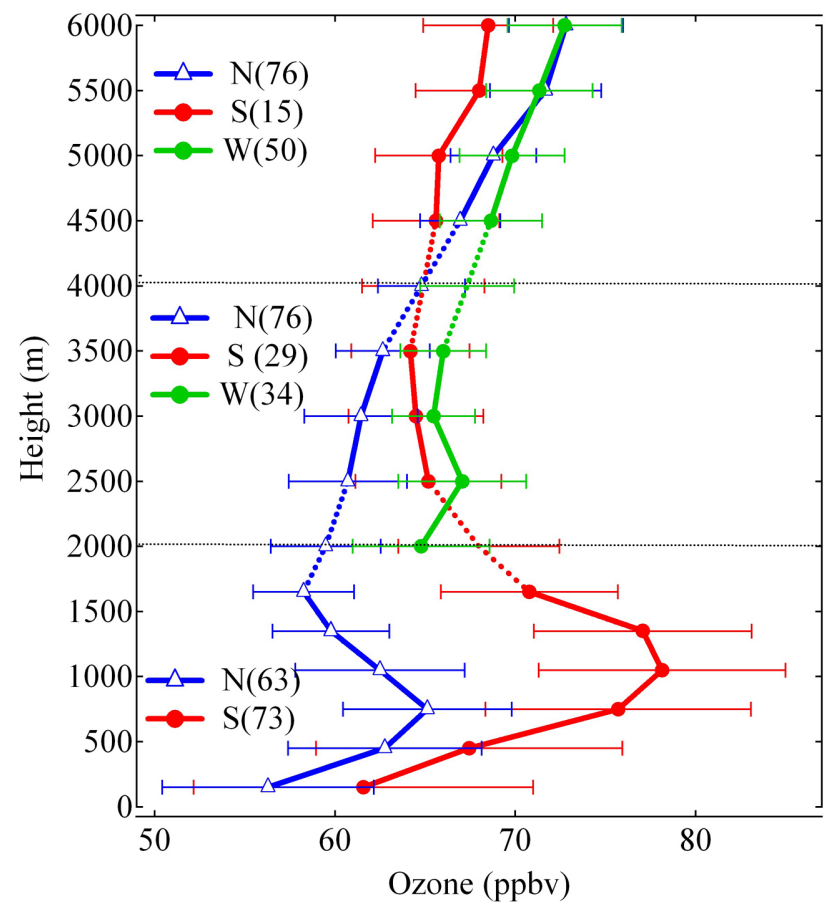

Fig. 10. Mean $\mathrm{O}_{3}$ distributions of different air mass types based on trajectory cluster analysis in the PBL $(0-2 \mathrm{~km})$, in lower free troposphere $(2-4 \mathrm{~km})$ and in the middle troposphere $(4-6 \mathrm{~km})$ over Beijing. Profile number of each category is given in the parentheses. Dashed line means an average of results classfied based on trajectory clusters calculated with different ending points (i.e. $1.2 \mathrm{~km}$, $3 \mathrm{~km}$ or $5 \mathrm{~km})$.

tropospheric ozone, which may be influenced by many processes/sources such as STE and biomass burnings as well. This topic can be further addressed in the future with the additional synchronous MOZAIC measurements of carbon monoxide $(\mathrm{CO})$ and total reactive nitrogen oxides $\left(\mathrm{NO}_{\mathrm{y}}\right)$ with $\mathrm{O}_{3}$ since 2002 (http://mozaic.aero.obs-mip.fr/web/).

\subsection{Decadal trend of lower tropospheric $\mathrm{O}_{3}$ over Beijing}

With a rapid industrialization and urbanization, emissions of ozone precursors in China are thought to have increased significantly (Richter et al., 2005). So far there has been no published result on the long-term trend of $\mathrm{O}_{3}$ on the Chinese subcontinent. Here we use MOZAIC data to attempt to derive a decadal tendency of lower tropospheric $\mathrm{O}_{3}$ over Beijing.

Because the number of MOZAIC samples in some years like 2000-2001 are too few to calculate the annual average, we made use of the data obtained during two periods, 1995-1999 and 2000-2005, to study the decadal trend. Figure 11 shows the vertical $\mathrm{O}_{3}$ profiles for the two periods averaged over year-round data and over summer afternoons only (LT 15:00-16:00, May-July). It can be seen that the mean 


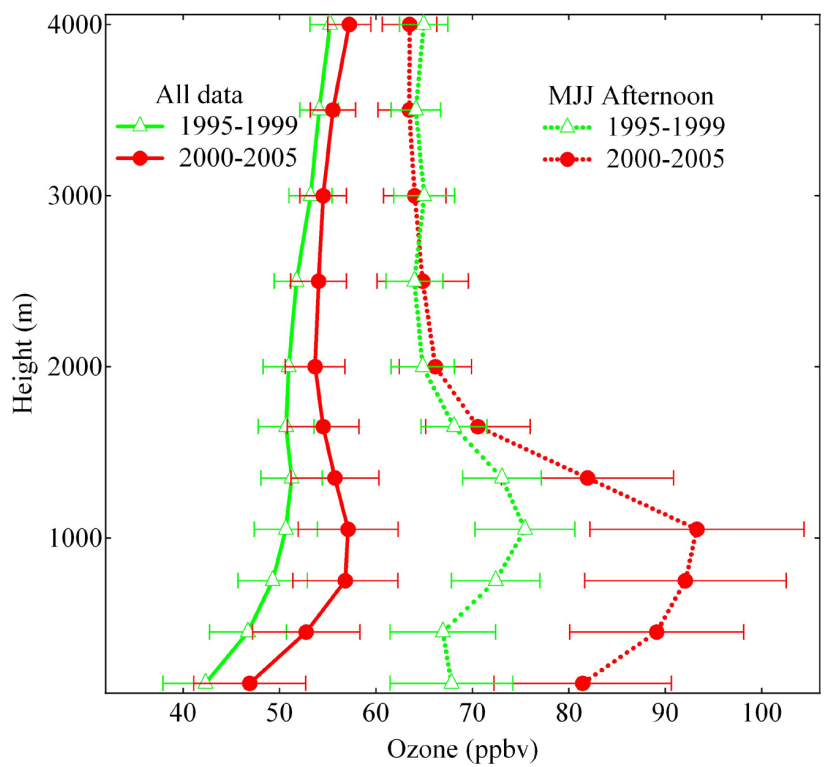

Fig. 11. Comparisons of mean $\mathrm{O}_{3}$ profiles in the lower troposphere over Beijing between 1995-1999 and 2000-2005. The solid lines are annual mean values, and the dashed lines on the right hand side represent the data collected in summer afternoons (at LT 15:0016:00 in MJJ).

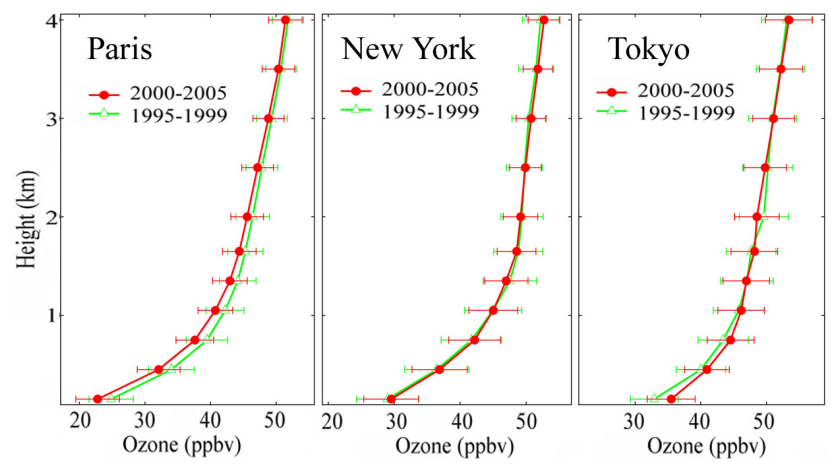

Fig. 12. Comparisons of annual mean $\mathrm{O}_{3}$ profiles between 19951999 and 2000-2005 in the lower troposphere over Paris, New York City, and Tokyo.

$\mathrm{O}_{3}$ level in lower troposphere has increased substantially in the last decade in Beijing. A variance analysis shows that the difference is statistically significant at a $95 \%$ confidential level for the year-round averages below $4 \mathrm{~km}$ and for summer results below $1.5 \mathrm{~km}$. The difference is about $5-8 \mathrm{ppbv}$ in the PBL with the largest increase at $1 \mathrm{~km}$ altitude. Considering 1997 and 2004 as the middle of the two periods (see Fig. 1b), the annual rate of change rate is about $1 \mathrm{ppbv} \mathrm{yr}^{-1}$, or about $2 \%$ for a mean level of 50 ppbv. For summer afternoons, a much larger increase (up to $22 \mathrm{ppbv}$ ) was found in the PBL with an increase rate of about $3 \mathrm{ppbv} \mathrm{yr}^{-1}$ (or

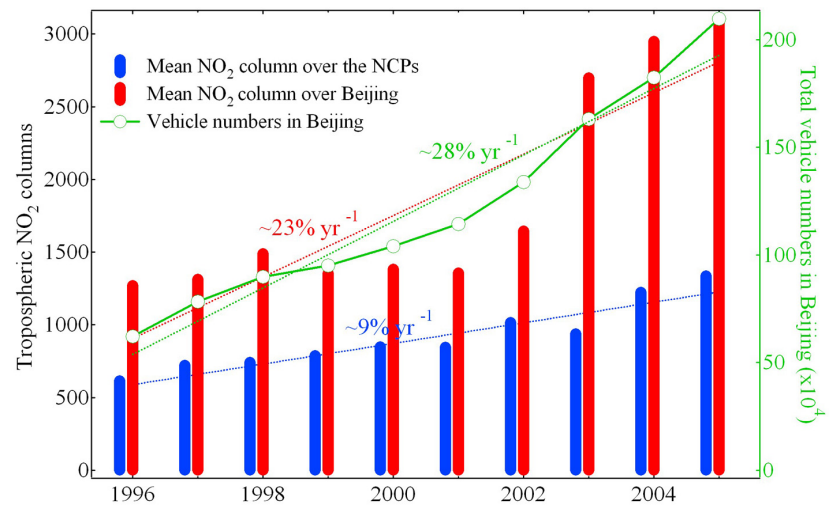

Fig. 13. Trends of annual mean tropospheric $\mathrm{NO}_{2}$ columns (Unit: $1 \mathrm{e}^{13}$ molecules $/ \mathrm{cm}^{2}$ ) in the NCPs and Beijing (data from GOME and SCIAMACHY), and annual total numbers of civilian vehicles in Beijing (Data from Chinese Statistical Yearbook 1996-2006).

$\sim 4 \%$ for a mean level of $75 \mathrm{ppbv}$ ). In contrast, the mean $\mathrm{O}_{3}$ concentrations in the free troposphere have not shown such an increase. The large increase in $\mathrm{O}_{3}$ in the boundary layer in Beijing is in sharp contrast to the situation in Paris, New York City and Tokyo. Figure 12 shows the mean $\mathrm{O}_{3}$ profiles during the same period for those three cities. Variance analysis indicates a statistically significant negative trend in Paris (below $3 \mathrm{~km}$ ), no trend in New York City, and a small positive trend (with a rate about $1 \%$ per year) below $450 \mathrm{~m}$ in Tokyo.

To investigate the possible influence of year-to-year difference in meteorological conditions to the ozone trend depending on the data mostly dominated by the year of 1997, 1998, and 2005, we examined the EL Nino index data (http://www.cpc.noaa.gov/products/ analysis_monitoring/ensostuff/ensoyears.shtml) which show strong El Nino signal during June 1997-April 1998. We further compared the annual sunshine hour, air temperature observed at the surface station and wind flows on different altitudes, but did not find significant difference for 1997, 1998 and 2005 over North China when compared to the 10-year average. More continuous data will be needed to further verify the ozone trend derived from our analysis.

To see if there exists a relationship between the observed $\mathrm{O}_{3}$ increase over Beijing and changes in emissions of $\mathrm{NO}_{2}$, an $\mathrm{O}_{3}$ precursor, in Fig. 13 we show GOME and SCIAMACHY retrieved tropospheric $\mathrm{NO}_{2}$ column in the NCPs (see dashed line box in Fig. 7$)$ and around Beijing $\left(1 \times 1^{\circ}\right.$ box centered at $\left.116.5^{\circ} \mathrm{E}, 40^{\circ} \mathrm{N}\right)$, together with the total number of civilian vehicles in Beijing City (http://www.stats.gov.cn/ tjsj/ndsj/) from 1996 to 2005. It can be seen that in the last decade both regional (NCPs) and Beijing urban emissions of $\mathrm{NO}_{\mathrm{x}}$ have sharply increased, particularly in urban Beijing (with a rate up to $23 \% \mathrm{yr}^{-1}$ ), and the latter correlated very well with a rapid increase in the total number of civilian 
vehicles in Beijing $\left(28 \% \mathrm{yr}^{-1}\right)$. These results strongly suggest that increasing anthropogenic emissions have enhanced tropospheric $\mathrm{O}_{3}$ over Beijing and possibly in other cities as well.

\section{Conclusions}

In this work we analyzed $\mathrm{O}_{3}$ data collected by the MOZAIC program from 1995 to 2005 and provided a first climatology of tropospheric $\mathrm{O}_{3}$ over Beijing and the surrounding areas. $\mathrm{O}_{3}$ over Beijing shows a similar vertical distribution to other northern mid-latitude locations, but has higher daytime $\mathrm{O}_{3}$ concentrations (up to $10 \mathrm{ppbv}$ ) in the lower troposphere than other mega-cities of similar latitudes. $\mathrm{O}_{3}$ exhibits a narrow early summer peak in June in the lower troposphere and a broad summer maximum in the middle troposphere. The June peak in the lower troposphere was attributed to favorable meteorological conditions conducive to photochemical production of $\mathrm{O}_{3}$ and transport of regional pollution and also to more intense biomass burning activities in the North China Plains.

Different from Tokyo, New York City, and Paris, the daytime $\mathrm{O}_{3}$ concentrations in the lower troposphere over Beijing have increased at a rate up to $2 \% \mathrm{yr}^{-1}$ during the past decade. This increasing trend is believed to be a result of increased anthropogenic emissions in Beijing and the surrounding areas. More research and management efforts are needed to address the high (and increasing) $\mathrm{O}_{3}$ concentrations in Beijing.

Acknowledgements. This work was funded by Hong Kong Research Grants Council (Project PolyU5144/04E), National Basic Research Program of China ('973 Project No.2005CB422203), and The Hong Kong Polytechnic University (Project 1-BB94 and G-YX86). The authors acknowledge for the strong support of the European Commission, Airbus, and the Airlines (Lufthansa, Austrian, Air France) who carry free of charge the MOZAIC equipment and perform the maintenance since 1994. MOZAIC is presently funded by INSU-CNRS (Institut National des Sciences de l'Univers - Centre National de la Recherche Scientifique, France), Météo-France, and FZJ (Forschungszentrum Jülich, Germany). The Final Anaylsis Data (FNL) were obtained from NOAA CDC, and HYSPLIT model and the formated FNL data were obtained from NOAA Air Resources Laboratory. Surface meteorological data were provided by the Data Support Section of the Computation and Information Systems Laboratory at the National Center for Atmospheric Research. GOME and SCIAMACHY data were provided by ESA through TEMIS.

Edited by: A. Stohl

\section{References}

Akimoto, H., Nakane, H., and Matsumoto, Y.: The chemistry of oxidant generation: tropospheric ozone increase in Japan, in: Chemistry of the Atmosphere: The Impact on Global Change, edited by: Calvert, J., Blackwell Scientific Publications, Oxford, UK, 261-273, 1994.

Akimoto, $\mathrm{H}$. and Narita, $\mathrm{H}$.: Distribution of $\mathrm{SO}_{2}, \mathrm{NO}_{\mathrm{x}}$, and $\mathrm{CO}_{2}$ emissions from fuel combustion and industrial activities in Asia with $1^{\circ} \times 1^{\circ}$ resolution, Atmos. Environ., 28(2), 213-225, 1994.

Austin, J. F. and Midgley, R. P.: The climatology of the jet-stream and stratospheric intrusions of ozone over Japan, Atmos. Environ., 28(1), 39-52, 1994.

Beekmann, M., Ancellet, G., and Megie, G.: Climatology of tropospheric ozone in southern Europe and its relation to potential vorticity, J. Geophys. Res., 99, 12 841-12 853, 1994.

Bojkov, R. D.: Ozone changes at the surface and in the free troposphere, in: Tropospheric Ozone: Regional and Global Scale Interactions, edited by: Isaksen, I. S. A., and Reidel, D., Dordrecht, Netherlands, 83-96, 1988.

Chan, C. Y., Chan, L. Y., Chang, W. L., Zheng, Y. G., Cui, H., Zheng, X. D., Qin, Y., and Li, Y. S.: Characteristics of a tropospheric ozone profile and implications for the origin of ozone over subtropical China in the spring of 2001, J. Geophys. Res., 108(D20), 8800, doi:10.1029/2003JD003427, 2003.

Cheung, V. T. F. and Wang, T.: Observational study of ozone pollution in rural site in the Yangtze Delta of China, Atmos. Environ., 35, 4947-4958, 2001.

Cooper, O. R., Stohl, A., Eckhardt, S., Parrish, D. D., Oltmans, S. J., Johnson, B. J., Nedelec, P., Schmidlin, F. J., Newchurch, M. J., Kondo, Y., and Kita, K.: A springtime comparison of tropospheric ozone and transport pathways on the east and west coasts of the United States, J. Geophys. Res., 110, D05S90, doi:10.1029/2004JD005183, 2005.

Crutzen, P. J.: A discussion of the chemistry of some minor constituents of the stratosphere and troposphere, Pure Appl. Geophys., 106-108, 1385-1399, 1973.

Ding, A. and Wang, T.: Influence of stratosphere-to-troposphere exchange on the seasonal cycle of surface ozone at Mount Waliguan in western China, Geophys. Res. Lett., 33(3), L03803, doi:10.1029/2005GL024760, 2006.

Ding, Y.: Monsoons Over China, Kluwer Acd., Norwell, Mass., 420 pp., 1994.

Fishman, J., Ramanathan, V., Crutzen, P. J., and Liu, S. C.: Tropospheric ozone and climate, Nature, 282, 818-820, 1979.

Fishman, J., Wozniak, A. E., and Creilson, J. K.: Global distribution of tropospheric ozone from satellite measurements using the empirically corrected tropospheric ozone residual technique: Identification of the regional aspects of air pollution, Atmos. Chem. Phys., 3, 893-907, 2003, http://www.atmos-chem-phys.net/3/893/2003/.

Gao, J., Wang, T., Ding, A. J., and Liu, C.: Observation study of ozone and carbon monoxide at the summit of mount Tai (1534 m a.s.1.) in central-eastern China, Atmos. Environ., 39, 4779-4791, 2005.

Hidy, G. M.: Ozone process insights from field experiments Part I: Overview, Atmos. Environ., 34, 2001-2022, 2000.

Kleinman, L., Lee, Y.-N., Springston, S. R., Nunnermacker, L., and Zhou, X. L.: Ozone formation at a rural site in the southeastern United States, J. Geophys. Res., 99, 3469-3482, 1994.

Lam, K. S., Wang, T. J., Chan, L. Y., Wang, T., and Harris, J.: Flow patterns influencing the seasonal behaviors of surface ozone and carbon monoxide at a coastal site near Hong Kong, Atmos. Environ., 35, 3121-3135, 2001. 
Law, K. S., Plantevin, P. H., Thouret, V., Marenco, A., Asman, W. A. H., Lawrence, M., Crutzen, P. J., Müller, J. F., Hauglustaine, D. A., and Kanakidou, M.: Comparison between global chemistry transport model results and Measurement of Ozone and Water Vapor by Airbus In-Service Aircraft (MOZAIC) data, J. Geophys. Res., 105(D1), 1503-1525, 2000.

Li, J., Wang, Z., Akimoto, H., Gao,C., Pochanart, P., and Wang, X.: Modeling study of ozone seasonal cycle in the lower troposphere over East Asia, J. Geophys. Res., 112, D22S25, doi:10.1029/2006JD008209, 2007.

Liu, J., Zhang, X. L., Zhang, X. C., and Tang, J.: Surface ozone characteristics and the correlated factors at Shangdianzi atmospheric background monitoring station, Research of Environmental Sciences (in Chinese), 19(4), 19-25, 2006.

Liu, S. C., Trainer, M., Fehsenfeld, F. C., Parrish, D. D., Williams, E. J., Fahey, D. W., Hubler, G., and Murphy, P. C.: Ozone production in the rural troposphere and the implications for regional and global ozone production, J. Geophys. Res., 92, 4191-5207, 1987.

Logan, J. A.: Tropospheric ozone: seasonal behavior trends, and anthropogenic influence, J. Geophys. Res., D6, 10 463-10482, 1985.

Logan, J. A.: Ozone in rural areas of the United States, J. Geophys. Res., 94, 8511-8532, 1989.

Logan, J. A.: Trends in the vertical distribution of ozone: An analysis of ozonesonde data, J. Geophys. Res., 99, 25, 553-25, 585, 1994.

Logan, J. A.: An analysis of ozonesonde data for the troposphere: Recommendations for testing 3-D models and development of a gridded climatology for tropospheric ozone, J. Geophys. Res., 104(D13), 16 115-16 149, 1999.

Luo, C, John, J. C. S., Zhou, X. J., Lam, K. S., Wang, T., and Chameides, W. L.:A nonurban ozone air pollution eipsode over eastern China: Observations and model simulations, J. Geophys. Res., 105(D2), 1889-1908, 2000.

Marenco, A., Thouret, V., Nedelec, P., Smit, H., Helten, M., Kley, D., Karcher, F., Simon, P., Law, K., Pyle, J., Poschmann, G., Wrede, R. V., Hume, C., and Cook, T: Measurement of ozone and water vapor by Airbus in-service aircraft: The MOZAIC airborne program, An overview, J. Geophys. Res., 103(D19), $25631-25642,1998$.

McKee, D. J.: Tropospheric ozone: human health and agricultural impacts, Lewis Publishers, New York, 9-18, 1994.

McKendry, I. G. and Lundgren, J.: Tropospheric layering of ozone in regions of urbanized complex and/or coastal terrain: a review, Prog. Phys. Geog., 24, 3, 329-354, 2000.

Monks, P. S.: A review of the observations and origins of the spring ozone maximum, Atmos. Environ., 34, 3545-3561, 2000.

Naja, M., and Akimoto H.: Contribution of regional pollution and long-range transport to the Asia - Pacific Region: Analysis of long-term ozonesonde data over Japan, J. Geophys. Res., 109, D21306, doi:10.1029/2004JD004687, 2004.

Nedelec, P., Thouret, V., Biroude, J., Sauvage, B., Cammas, J.P., and Stohl, A.: Extreme $\mathrm{CO}$ concentrations in the upper troposphere over the northeast Asia in June 2003 from the in situ MOZAIC aircraft data, Geophys. Res. Lett. 32, L14807, doi:10.1029/2005GL023141, 2005.

Neu, U., Kunzle, T., and Wanner, H.: On the relation between ozone storage in the residual layer and daily variation in near-surface ozone concentration - a case study, Bound.-Lay. Meteorol., 69, 221-247, 1994.

NRC (National Research Council): Rethinking the Ozone Problem in Urban and Regional Air Pollution, National Academy Press, Washington, D.C., 1991.

Oltmans, S. J., Lefohn, A. S., Scheel, H. E., Harris, J. M., Levy II, H., Galbally, I. E., Brunke, E. G., Meyer, C. P., Lathrop, J. A., Johnson, B. J., Shadwick, D. S., Cuevas, E., Schmidlin, F. J., Tarasick, D. W., Claude, H., Kerr, J. B., Uchino, O., and Mohnen, V.: Trends of ozone in the troposphere, Geophys. Res. Lett., 25, 139-142, 1998.

Pochanart, P., Akimoto, H., Kinjo, Y., and Tanimoto, H.: Surface ozone at four remote island sites and the preliminary assessment of the exceedances of its critical level in Japan, Atmos. Environ., 36, 4235-4250, 2002.

Pochanart, P., Akimoto, H., Kajii, Y., Potemkin, V. M., and Khodzher, T. V.: Regional background ozone and carbon monoxide variations in remote Siberia/East Asia, J. Geophy. Res., 108(D1), 4028, doi:10.1029/2001JD001412, 2003.

Qin, S. G., Ding, A. J., and Wang, T.: Transport pattern of biomass burnings air masses in Eurasia and the impacts on China, China Environ. Sci., 26(6), 641-645, in Chinese, 2006.

Real, E., Law, K. S., Weinzierl, B., Fiebig, M., Petzold, A., Wild, O., Methven, J., Arnold, S., Stohl, A., Huntrieser, H., Roiger, A., Schlager, H., Stewart, D., Avery, M., Sachse, G., Browell, E., Ferrare, R., and Blake, D.: Processes influencing ozone levels in Alaskan forest fire plumes during long-range transport over the North Atlantic, J. Geophys. Res., 112, D10S41, doi:10.1029/2006JD007576, 2007.

Reiter, R.: On the mean daily and seasonal variations of the vertical ozone profiles in the lower troposphere, Atmos. Environ., 25A, 1751-1757, 1991.

Richter, A., Burrows, J. P., Nub, H., Granier, C., and Niemeier, U.: Increase in tropospheric nitrogen dioxide over China observed from space, Nature, 437, 129-132, 2005.

Shao, M., Tang, X. Y., Zhang, Y. H., and Li, W. J.: City clusters in China: air and surface water pollution, Front. Ecol. Environ., 4(7), 353-361, 2006.

Streets, D. G., Bond T. C., Carmichael, G. R., Fernandes, S. D., Fu, Q., He, D., Klimont, Z., Nelson, S. M., Tsai, N. Y., Wang, M. Q., Woo, J. H., and Yarber, K. F.: An inventory of gaseous and primary aerosol emissions in Asia in the year 2000, J. Geophys. Res., 108(D21), 8809, doi:10.1029/2002JD003093, 2003.

Taylor, J. K. and Cihon, C.: Statistical Techniques for data analysis, Second Edition, Chapman and Hall/CRC, 2004.

Thouret, V., Marenco, A., Nedelec, P., and Grouhel, C.: Ozone climatologies at $9-12 \mathrm{~km}$ altitude as seen by the MOZAIC airborne program between September 1994 and August 1996, J. Geophys. Res., 103(D19), 25 653-25 679, 1998a.

Thouret, V., Marenco, A., Logan, J. A., Nedelec, P., and Grouhel, C.: Comparison of ozone measurements from the MOZAIC airborne program and the ozone sounding network at eight locations, J. Geophys. Res., 103(D19), 25 695-25 720, 1998 b.

Thouret, V., Cammas, J. P., Sauvage, B., Athier, G., Zbinden, R., Nedelec, P., Simon, P., and Karcher, F.: Tropopause referenced ozone climatology and inter-annual variability (1994-2003) from the MOZAIC programme, Atmos. Chem. Phys., 6, 1033-1051, 2006, http://www.atmos-chem-phys.net/6/1033/2006/. 
Wang, T., Cheung, T. F., Anson, M., and Li, Y. S.: Ozone and related gaseous pollutants in the boundary layer of eastern China: Overview of the recent measurements at a rural site, Geophys. Res. Lett., 28, 2373-2376, 2001.

Wang, T., Cheung, T. F., Li, Y. S., Yu, X. M., and Blake, D. R.: Emission characteristics of $\mathrm{CO}, \mathrm{NO}_{\mathrm{x}}, \mathrm{SO}_{2}$ and indications of biomass burning observed at a rural site in eastern China, J. Geophys. Res., 107, 4157-4167, 2002.

Wang, T., Ding, A. J., Gao., J., and Wu, W. S.: Strong ozone production in urban plumes from Beijing, China, Geophys. Res. Lett., 33(21), L21806, doi:10.1029/2006GL027689, 2006a.

Wang, T., Guo, H., Blake, D. R., Kwok, Y. H., Simpson, I. J., and Li, Y. S.: Measurements of trace gases in the inflow of South China Sea background air and outflow of regional pollution at Tai' O, Southern China, J. Atmos. Chem., 52(3), 295-317, 2005.

Wang, T. and Kwok, J. Y. H.: Measurement and analysis of a multiday photochemical smoge episode in the Pearl River Delta of China, J. Appl. Meteorol., 42, 404-416, 2003.

Wang, T., Wong, H. L. A., Tang, J., Ding, A., Wu, W. S., and Zhang, X. C.: On the origin of surface ozone and reactive nitrogen observed at a remote mountain site in the northeastern Qinhai-Tibetan Plateau, western China, J. Geophys. Res., 111, D08303, doi:10.1029/2005JD006527, 2006b.
Xu, X. B., Lin, W. L., Wang, T., Yan, P., Tang, J., Meng, Z. Y., and Wang, Y.: Long-term trend of surface ozone at a regional background station in eastern China 1991-2006: Enhanced variability, Atmos. Chem. Phys. Discuss., in press, (acpd-2007-0473), 2007.

Zbinden, R. M., Cammas, J. P., Thouret, V., Nedelec, P., Karcher, F., and Simon, P.: Mid-latitude tropospheric ozone columns from the MOZAIC program: climatology and inter-annual variability, Atmos. Chem. Phys., 6, 1053-1073, 2006, http://www.atmos-chem-phys.net/6/1053/2006/.

Zheng, X. D., Zhou, X. J., Tang, J., Qin, Y., and Chan, C. Y.: A meteorological analysis on a low tropospheric ozone event over Xining, North Western China on 26-27 July 1996, Atmos. Environ., 38(2), 261-271, 2004. 